\title{
PENGEMBANGAN VIRTUAL LAB BERBASIS ANDROID PADA MATERI ASAM BASA UNTUK SISWA SMA
}

\author{
M. Muchson ${ }^{1 *}$, Munzil ${ }^{1}$, Betti Elgavita Winarni ${ }^{1}$, Dwi Agusningtyas ${ }^{1}$ \\ ${ }^{1}$ Jurusan Kimia FMIP A Universitas Negeri Malang, Jl. Semarang No. 5 Malang
}

\begin{abstract}
Abstrak - Masalah yang berkaitan dengan praktikum bisa menjadi alasan mengapa siswa tidak dapat memahami kimia dengan baik. Pada dasarnya, dengan melakukan praktikum konfirmatif, siswa menjadi tidak kreatif karena tidak memiliki banyak kesempatan untuk mengeksplorasi percobaan. Selain itu, praktikum di laboratorium nyata tidak menunjang pemahaman konseptual siswa pada tingkat sub-mikroskopis yang merupakan salah satu persyaratan dalam memahami topik kimia seperti asam basa. Oleh karena itu, penelitian ini bertujuan untuk mengembangkan virtual lab berbasis android sebagai sumber belajar bagi siswa SMA pada topik asam basa. Virtual lab dalam penelitian ini dikembangkan dengan mengadaptasi model pengembangan pembelajaran multimedia oleh Lee dan Owens (2004). Tingkat kelayakan virtual lab hasil pengembangan dari segi fungsinya sebagai media pembelajaran berdasarkan hasil penilaian oleh pakar dan pengguna adalah $85,44 \%$; sedangkan dari segi akurasi konsep adalah 84,67\%, sehingga virtual lab yang dikembangkan dapat dikategorikan sangat layak untuk diimplementasikan sebagai media pembelajaran. Virtual lab hasil pengembangan diujicoba pada 12 siswa SMA; dan setelah itu mereka diminta untuk memberikan persepsi kuantitatif terhadap virtual lab menggunakan kuesioner dan hasilnya sebesar 89,27\%. Hal ini juga mendukung tingkat kelayakan virtual lab sebagai media pembelajaran. Keunggulan virtual lab hasil pengembangan meliputi: (1) dilengkapi dengan pretes untuk mendukung kesiapan siswa sebelum praktikum dan postes untuk mengukur tingkat pencapaian pemahaman siswa setelah menggunakan produk; (2) dilengkapi dengan visualisasi partikulat yang menunjang pemahaman konseptual siswa pada level sub-mikroskopis; (3) dapat digunakan secara linear atau nonlinier dengan memilih menu yang diinginkan; (4) efisiensi alat, bahan dan waktu meskipun simulasi dilakukan sesering yang diinginkan siswa.
\end{abstract}

Kata kunci: Pengembangan Media Pembelajaran; Virtual Lab; Android; Asam Basa.

\begin{abstract}
The problems related to laboratory activities could be a reason why students could not understand chemistry well. Basically, by doing confirmative lab activities in the real laboratory, students could not be creative since they do not have more chances to explore the experiments. In addition, lab activities in the real laboratory could not support conceptual understanding of students on sub-microscopic level which is one of the requirements in understanding chemistry topics such as acid base. Therefore, this research aims to develop an android-based virtual labs as learning resource to support senior high school students during their study on the topic of acid base. The virtual lab was developed by adapting the model of developing learning multimedia by Lee and Owens (2004). The feasibility level of the virtual lab developed in term of its function as a learning media based on the results of assessment by expert and users is $85.44 \%$; while in terms of concepts accuration is $84.67 \%$, so the virtual lab developed can be categorized as very feasible to be implemented as learning media. The virtual lab developed was tested to 12 of senior high school students; and afterward they are required to give quantitative perceptions toward the virtual lab developed using questionnaire. The results of quantitative perceptions is $89.27 \%$ : so this also supports the feasibility level of virtual lab as a learning media. The excellences of virtual lab developed include: (1) equipped with pretest to support students' readiness before lab activities and posttest to measure the students' achievement after using the product; (2) equipped with visualization of particulate of matter that supports conceptual understanding of students on sub-microscopic levels; (3) can be used linearly or nonlinearly by selecting the desired menu; (4) the efficiency of tools, materials and time even though the simulations are carried out as often as students want.
\end{abstract}

Keywords: Learning Media Development; Virtual Lab; Android; Acid Base.

*Corresponding author: Jurusan Kimia, Universitas Negeri Malang, Malang 65145, Indonesia. Email: m.muchson.fmipa@um.ac.id 


\section{PENDAHULUAN}

Praktikum merupakan salah satu kegiatan untuk memberikan pemahaman pada siswa mengenai suatu materi. Siswa dapat memahami dan menyelesaikan masalah terkait konsep yang diajarkan di kelas serta mendapatkan pemahaman yang mendalam melalui proses saintifik dalam kegiatan praktikum (Lang, 2012; Makransky, 2016). Praktikum memiliki kedudukan yang sangat penting untuk mendukung penjelasan teoritis yang ada dalam pembelajaran kimia (Kurbanoglu \& Akim, 2010).

Kegiatan praktikum dalam pembelajaran kimia yang umum dilakukan di tingkat SMA adalah jenis praktikum pada level inkuiri konfirmatif. Pada level ini, siswa melakukan praktikum berdasarkan permasalahan, prosedur, teknik analisis dan interpretasi data yang sudah disiapkan oleh guru dalam bentuk buku petunjuk praktikum (Buck, et al., 2008). Praktikum konfirmatif masih sering digunakan karena dapat melakukan banyak praktikum pada kelas dengan jumlah siswa yang banyak dengan waktu dan sumber yang terbatas.

Salah satu materi kimia di SMA yang membutuhkan praktikum untuk menunjang pemahaman siswa adalah asam basa. Asam basa termasuk materi yang padat karena melibatkan banyak konsep, yaitu sifat dan pengertian asam dan basa, teori asam-basa, kekuatan asam-basa, netralisasi, titrasi, $\mathrm{pH}$, indikator, kesetimbangan asam-basa, dan larutan penyangga (Sheppard, 2006). Pada umumnya, praktik pembelajaran pada materi asam basa masih terbatas pada tataran penjelasan verbal dan praktikum yang dilakukan adalah untuk memverifikasi hasil yang diharapkan dalam modul praktikum atau oleh guru (Rahayu, dkk., 2011).

Berdasarkan hasil wawancara yang dilakukan secara tidak terstruktur terhadap 3 orang guru SMA Laboratorium UM dan 5 orang peserta Program Pendidikan Profesi Guru Dalam Jabatan (PPG DJ) tahun 2018, kendala yang terjadi pada praktikum asam basa umumnya adalah siswa kurang memiliki kesiapan sebelum memasuki laboratorium. Berkaitan dengan kesiapan siswa, hal ini terjadi karena siswa tidak mencari informasi terlebih dahulu terkait praktikum yang akan dilakukan, sehingga banyak waktu yang terbuang untuk menyiapkan siswa pada kegiatan pra-lab untuk praktikum identifikasi larutan asam dan basa serta pengukuran $\mathrm{pH}$ larutan. Guru harus menjelaskan mengenai cara memodelkan/mensimulasikan penggunaan alat dan bahan terkait praktikum yang akan dilakukan, serta seringkali harus menjelaskan kembali konsep awal mengenai materi yang terkait dengan asam basa.

Berdasarkan hasil wawancara juga diperoleh informasi bahwa keterbatasan alat dan bahan menjadi kendala lain yang umum dalam pelaksanaan kegiatan praktikum untuk materi asam basa di sekolah. Fakta tersebut didukung oleh Amry (2013) yang menyatakan bahwa pembelajaran praktikum pada titrasi asam-basa di SMAN 9 Malang tidak dilakukan seluruhnya karena keterbatasan alat, bahan, dan waktu. Penggunaan metode praktikum untuk membelajarkan materi titrasi asam basa yang dilakukan di tingkat SMA umumnya terbatas pada titrasi asam kuat-basa kuat. Praktikum titrasi asam kuat-basa kuat tidak memberikan pengalaman kepada siswa tentang kondisi saat terjadi larutan penyangga maupun garam yang terhidrolisis menghasilkan sifat asam atau basa dalam larutan. Hal ini mengakibatkan siswa tidak memiliki pemahaman secara utuh terhadap materi titrasi asam basa. Kelemahan lain dari praktikum yang sudah diatur oleh prosedur umumnya adalah siswa tidak dapat berkreasi untuk mencoba-coba kondisi lain atau berlatih terlebih dahulu sebelum dilaksanakan kegiatan praktikum. Selain itu, praktikum dalam laboratorium juga belum dapat menunjang aspek sub-mikroskopik yang menjadi salah satu tuntutan dalam mempelajari materi kimia seperti asam basa.

Perkembangan ilmu pengetahuan dan teknologi terus mendorong berbagai upaya pembaruan untuk pemanfaatan hasil teknologi dalam proses belajar (Arsyad, 2014:2). Hal ini dapat ditunjukkan dengan pemanfaatan smartphone sebagai media pembelajaran karena siswa memiliki kecenderungan dalam memanfaatkan hasil pembaruan teknologi untuk menambah pengetahuan mereka dalam belajar (Huang, 2004). Dewasa ini, hampir semua lapisan masyarakat termasuk siswa 
memilih menggunakan smartphone dengan sistem operasi android karena android merupakan platform yang ideal untuk menyebarkan materi pelajaran kepada siswa dalam bentuk aplikasi (Chao, 2012). Perkembangan teknologi yang mempengaruhi pola belajar siswa tersebut dapat direspon dengan pengembangan virtual lab untuk mengatasi permasalahan praktikum seperti disebutkan di atas. Virtual lab dapat dijalankan pada smartphone berbasis android sehingga mudah dibawa kemana saja dan tanpa memerlukan akses internet. Keunggulan ini dapat dimanfaatkan untuk memfasilitasi siswa dalam belajar guna meningkatkan pemahaman konsep pada aspek kognirif dan psikomotorik dalam pembelajaran kimia berbasis praktikum.

Berdasarkan kendala dalam pelaksanaan praktikum asam basa tersebut, solusi alternatif yang dapat dilakukan adalah dengan menggunakan media pembelajaran virtual lab yang dapat membantu siswa memahami konsep dengan melakukan simulasi praktikum. Virtual lab berfungsi sebagai sarana untuk membantu siswa dalam persiapan pra-lab, memperkuat pemahaman konsep siswa, dan sebagai pengganti atau pelengkap real lab karena siswa dapat mengulang simulasi praktikum yang tidak dipahami (Hawkins \& Phelps, 2013; Tatli \& Ayas, 2010). Diharapkan materi kimia yang padat seperti asam basa menjadi lebih mudah dipahami terutama pada teknik dan konsep dasar yang digunakan dalam praktikum dengan menggunakan virtual lab (Jagodzinski \& Wolsky, 2015; Jiménez, 2003). Selain itu, gambaran mikroskopik yang disajikan pada virtual lab dapat digunakan untuk membantu siswa dalam memahami konsep.

Berbagai media virtual lab telah dikembangkan seperti media yang dikembangkan oleh Lutfi (2017) untuk menentukan sifat larutan menggunakan $\mathrm{pH}$ meter dengan dilengkapi beberapa macam larutan yang dapat dimanipulasi konsentrasinya; Tarwiyah (2014) mengembangkan virtual lab dari PhET pada larutan asam-basa untuk menentukan sifat larutan dan menghitung $\mathrm{pH}$ larutan; dan Amry (2013) mengembangkan multimedia pembelajaran pada praktikum titrasi asam-basa yang menampilkan simulasi praktikum disertai gambaran mikroskopik dan kurva titrasi yang dijalankan pada komputer/laptop. Namun, virtual lab tersebut hanya dapat dijalankan dengan menggunakan komputer/laptop dan dibuat secara terpisah. Oleh karena itu, peneliti bermaksud mengembangkan virtual lab sejenis yang dapat dijalankan pada smartphone android dan komputer/laptop yang memiliki emulator android dengan menggabungkan konten simulasi praktikum berbasis konfirmatif dari virtual lab yang telah dikembangkan sebelumnya. Konten tersebut meliputi: (1) penentuan sifat dan pengukuran $\mathrm{pH}$ larutan menggunakan beberapa indikator yang digunakan sebagai pelengkap praktikum untuk memahamkan konsep kepada siswa; serta (2) simulasi praktikum titrasi asam-basa yang terdiri dari empat jenis titrasi yang dapat digunakan sebagai pengganti praktikum. Demi tercapainya harapan tersebut, maka peneliti bermaksud untuk menghasilkan virtual lab berbasis android pada materi asam basa untuk siswa kelas XI SMA yang layak digunakan sebagai salah satu sumber belajar bagi siswa.

\section{METODE}

Produk virtual lab berbasis android pada materi asam basa untuk siswa kelas XI SMA dikembangkan dengan mengadaptasi model pengembangan menurut Lee dan Owens (2004:3) yang terdiri dari lima tahap. Urutan kelima tahapan tersebut diberikan pada Gambar 1. Tahapan yang pertama adalah tahap penilaian/analisis. Tahapan ini terdiri dari dua bagian yaitu needs assessment (penilaian kebutuhan) dan front-end analysis (analisis awal-akhir). Tahapan needs assessment dilakukan dengan melakukan wawancara langsung terhadap guru kimia SMA dengan tujuan untuk mengetahui kondisi lapangan dengan membandingkan praktik pembelajaran di lapangan dengan kurikulum yang berlaku. Tahapan analisis awal-akhir yang dilakukan meliputi audience analysis (analisis siswa), technology analysis (analisis teknologi), critical incident analysis (analisis kejadian penting), objective analysis (analisis tujuan), dan media analysis (analisis media). 


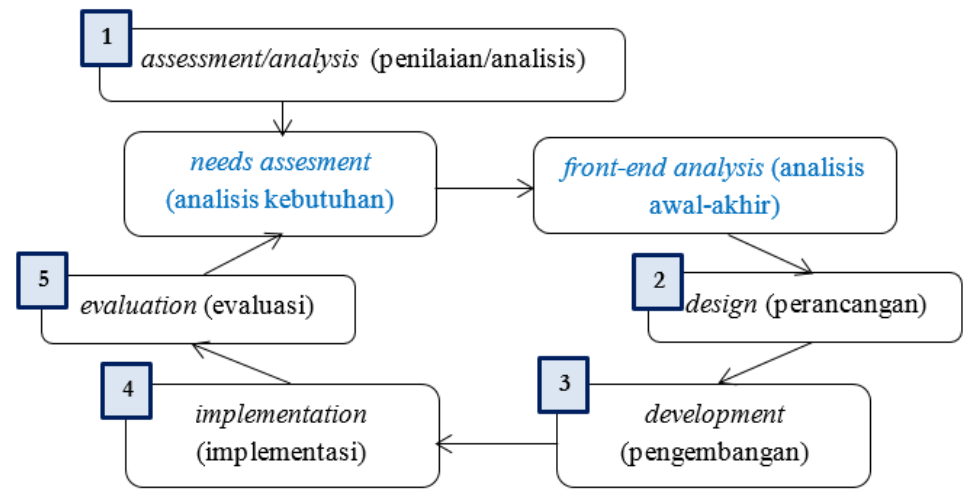

Gambar 1. Skema Prosedur Pengembangan Media Adaptasi Model Perancangan Multimedia Pembelajaran Menurut Lee dan Owens (2004:3)

Analisis siswa dilakukan dengan menganalisis karakteristik siswa meliputi kemampuan kognitif dan kebiasaan belajar siswa; Analisis teknologi dilakukan terhadap smartphone android dan program converter yang akan digunakan; Analisis kejadian penting dilakukan dengan menentukan submateri yang digunakan sebagai konten virtual lab yang dikembangkan yakni dengan menelaah buku kimia SMA kelas XI mengenai materi asam basa yang disesuaikan dengan kurikulum 2013; Analisis tujuan dilakukan untuk menentukan indikator pencapaian pembelajaran berdasarkan submateri yang dipilih pada virtual lab yang dikembangkan; Analisis media dilakukan dengan memilih media yang sesuai meliputi penentuan bentuk dan isi dari media yang dibutuhkan.

Tahapan kedua yaitu perancangan dimana peneliti melakukan perancangan struktur materi yang disajikan pada virtual lab yang dikembangkan serta penyusunan perangkat untuk pelaksanaan validasi dan uji coba. Tahapan ketiga yaitu pengembangan dimana peneliti membuat storyboard dan pemrograman. Tahapan keempat yaitu implementasi dimana dilakukan penilaian kelayakan terhadap produk pengembangan baik dari fungsinya sebagai media pembelajaran maupun kebenaran dan kejelasan konsep materi. Penilaian kelayakan dilakukan oleh seorang pakar yang merupakan Kepala Pusat Pengambangan Sumber Belajar dari Lembaga Pengembangan Pendidikan (LP3) Universitas Negeri Malang dan memiliki latar belakang pendidikan bidang Kimia Analitik, serta pengguna yaitu dua orang Guru Kimia SMA di Kota Malang. Selain itu, pada tahapan ini juga dilakukan uji coba terhadap kelompok kecil yaitu 12 orang siswa kelas XI IPA SMAN 8 Malang. Ujicoba dilakukan dengan memberikan produk pengembangan kepada setiap siswa untuk digunakan dalam pembelajaran mandiri. Setelah ujicoba selesai dilakukan, setiap siswa diminta untuk mengemukakan persepsinya secara kuantitatif melalui angket. Tahapan terakhir adalah evaluasi dimana peneliti melakukan analisis data berdasarkan hasil validasi dan uji coba pada tahap implementasi dan melakukan revisi produk berdasarkan komentar dan saran yang diperoleh dari pakar, pengguna dan siswa hingga didapatkan produk pengembangan yang lebih baik.

\section{HASIL DAN PEMBAHASAN}

Produkpengembangan virtual lab berbasis android pada materi asam basa untuk siswa kelas XI SMA memiliki format APK. Aplikasi tersebut diberi nama ABC Lab yang merupakan singkatan dari Acid Base Chemistry Laboratory. Virtual lab yang dihasilkan dapat dijalankan secara nonlinier yaitu tanpa harus menjalankan simulasi praktikum yang ada secara berurutan. Namun, untuk memahami materi praktikum asam basa secara menyeluruh siswa dihimbau untuk menggunakan virtual lab secara linier atau berurutan. Penggunaan secara linier pada aplikasi tersebut dengan ketentuan sebagai berikut:

1) Menyelesaikan pretest,

2) Menjalankan simulasi praktikum asam basa yang meliputi praktikum identifikasi larutan asam dan basa, pengukuran $\mathrm{pH}$ larutan, dan titrasi asam-basa;

3) Mengerjakan posttest. 
Aplikasi yang dihasilkan memiliki sebelas bagian, antara lain bagian pertama adalah Halaman awal yang terdiri dari tiga bagian yakni halaman loading, splash screen, dan cover. Tampilan halaman awal diberikan pada Gambar 2. Bagian kedua adalah Halaman menu pretest dan soal pretest untuk menguji pengetahuan awal siswa mengenai materi asam basa serta sebagai prasyarat untuk melaksanakan simulasi praktikum di ABC Lab. Pada dasarnya fungsi pretes dalam kegiatan praktikum konfirmatif lebih menekankan pada kesiapan siswa dengan mengingat kembali prinsip-prinsip dasar yang sudah dipelajari berkaitan dengan materi yang akan dipraktikumkan. Tampilan halaman menu pretest dan soal pretest diberikan pada Gambar 3.

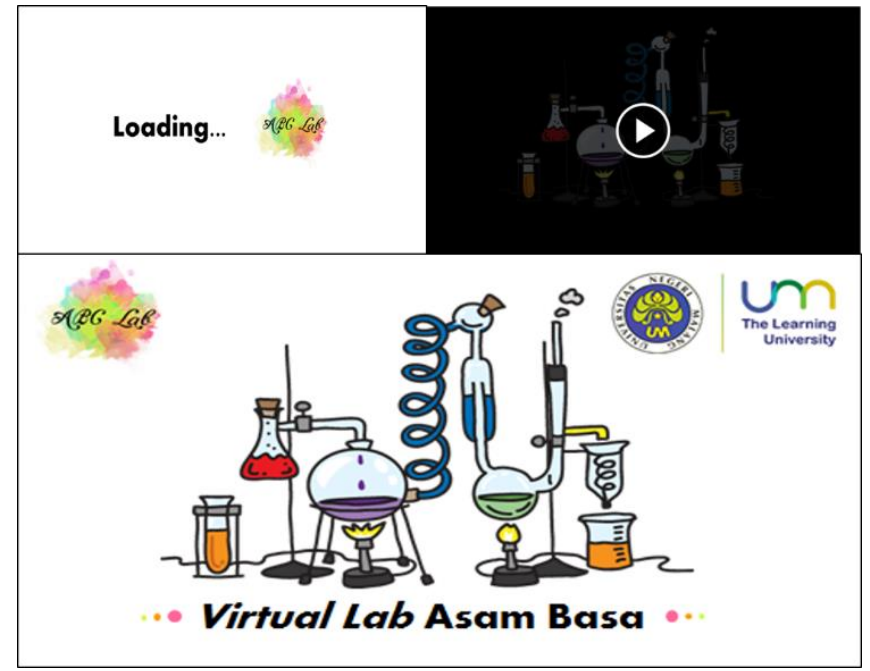

Gambar 2. Contoh Halaman Awal pada Aplikasi ABC Lab
yang terdiri dari Halaman Loading, Splash Screen, dan Cover

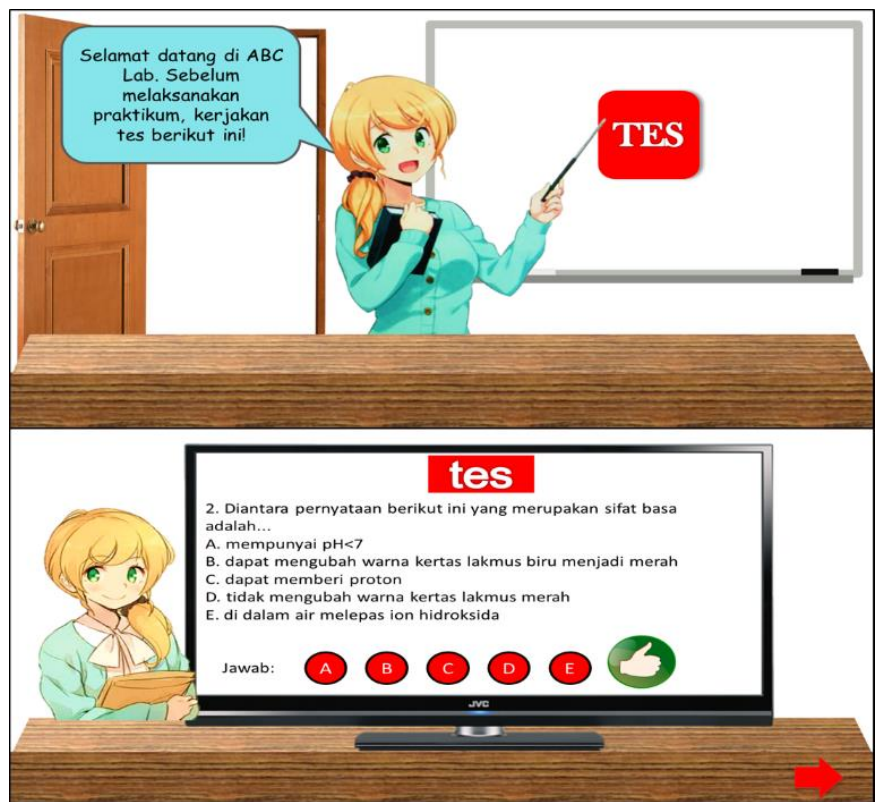

Gambar 3. Contoh Halaman Menu Pretest dan Soal Pretest pada Aplikasi ABC Lab

Bagian ketiga adalah Halaman menu utama yang berisi sajian pilihan praktikum terkait asam basa yang ada pada virtual lab yang dikembangkan. Tampilan halaman menu utama diberikan pada Gambar 4. Bagian keempat adalah Halaman menu pilihan praktikum yang menampilkan menu pilihan praktikum dalam bentuk gambar buku petunjuk praktikum yang menunjukkan identitas praktikum yang akan dilakukan. Tampilan halaman menu pilihan praktikum diberikan pada Gambar 5. Penyajian dalam format menu bertujuan untuk memudahkan siswa dalam memilih simulasi praktikum yang diinginkan, sehingga siswa dapat menjalankan aplikasi ini secara nonlinier atau tidak berurutan. Kelebihan ini dapat menunjang kebutuhan siswa dalam pembelajaran mandiri 
dimana siswa dapat mengulangi praktikum sesering yang diinginkan karena umumnya kecepatan atau tipe belajar setiap siswa berbeda. Scheckler (2003) mengemukakan bahwa virtual lab memungkinkan siswa mengulangi simulasi yang kurang dipahami atau sebagai ulasan untuk ujian dan mampu mendukung kemampuan untuk melakukan praktikum dengan hal yang terlalu berbahaya dan terlalu lama untuk dilakukan di laboratorium. Kegiatan mengulangi praktikum tersebut juga menjadi lebih efisien karena tidak memerlukan tambahan alat atau bahan lagi. Hal ini dikuatkan oleh pendapat Jong (2013) yang menyatkan bahwa praktikum yang dilakukan secara virtual lebih efisien dibandingkan dengan praktikum fisik karena memerlukan waktu yang lebih singkat dengan hasil yang tepat secara instan.

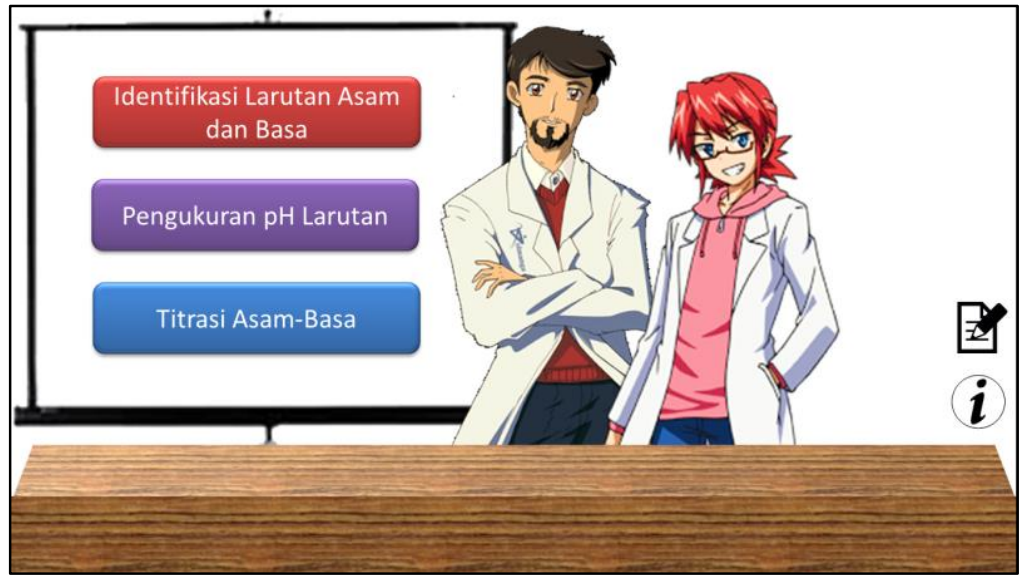

Gambar 4. Contoh Halaman Menu Utama pada Aplikasi ABC Lab

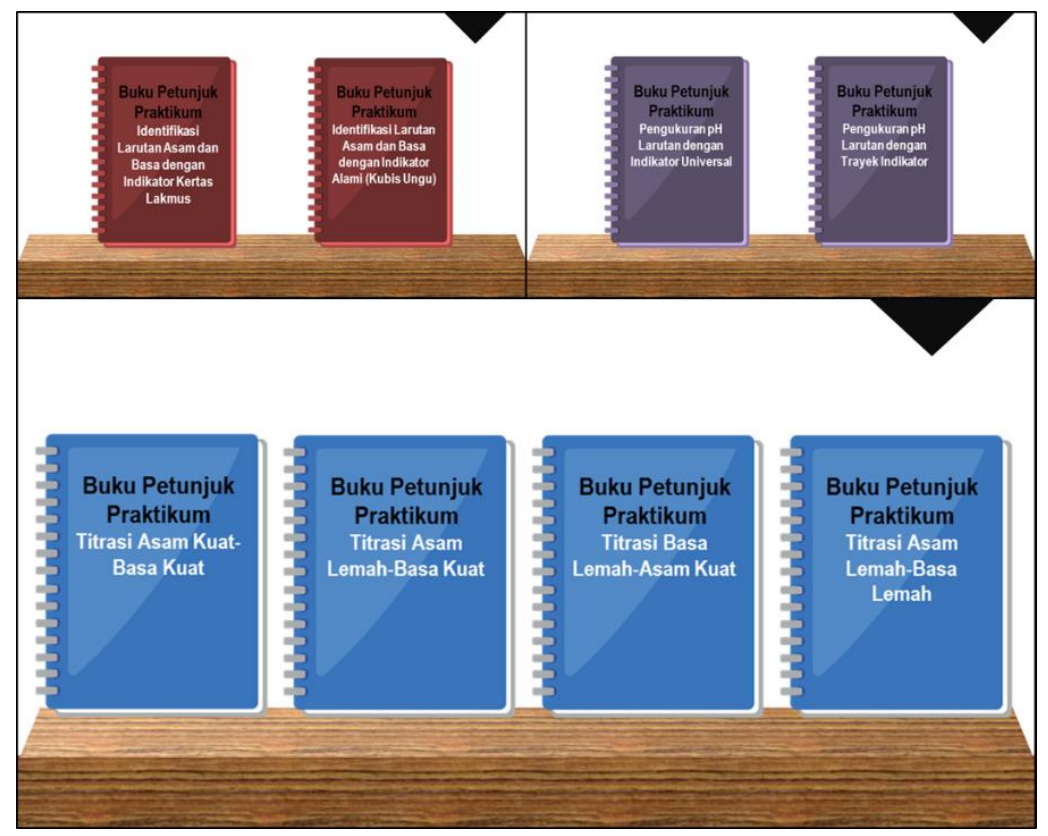

Gambar 5. Contoh Halaman Menu Pilihan Praktikum pada Aplikasi ABC Lab

Bagian kelima adalah Halaman persiapan praktikum yang dimulai dengan pemilihan alat dan bahan untuk jenis praktikum tertentu. Halaman pemilihan alat dan bahan menggambarkan seolah-olah siswa berada di laboratorium dengan dibimbing oleh seorang laboran yang akan membantu melatih konsentrasi siswa dan menguji pengetahuan siswa dalam memilih alat dan bahan yang sesuai dengan simulasi praktikum yang akan dilakukan. Halaman ini dilanjutkan dengan bagian keenam yaitu Halaman sajian alat dan bahan yang tepat yang bertujuan untuk membantu siswa mengetahui alat dan bahan yang sesuai untuk digunakan dalam simulasi jenis praktikum tertentu. Tampilan halaman pemilihan alat dan bahan serta Halaman sajian alat dan bahan yang tepat atau sesuai dengan jenis praktikum tertentu disajikan pada Gambar 6 dan 7. 


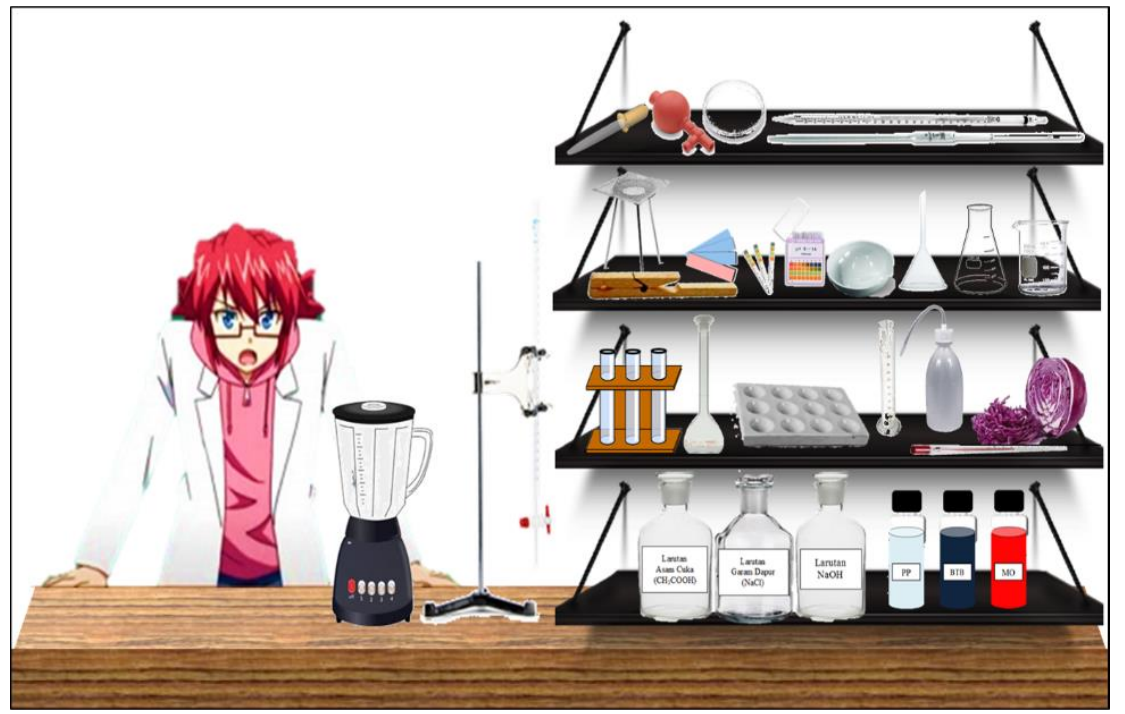

Gambar 6. Contoh Halaman Pemilihan Alat dan Bahan pada Aplikasi ABC Lab

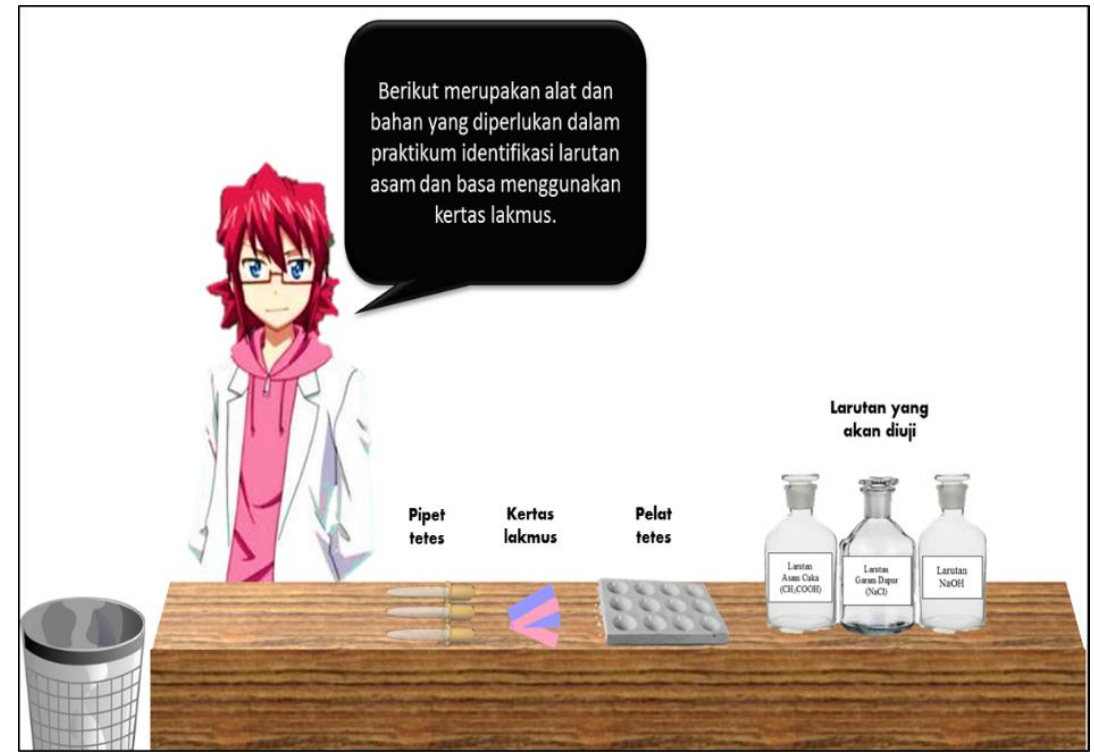

Gambar 7. Contoh Halaman Sajian Alat dan Bahan yang Sesuai pada Aplikasi ABC Lab

Bagian ketujuh merupakan Halaman petunjuk yang menampilkan langkah-langkah dalam bentuk verbal dalam melakukan jenis praktikum tertentu. Halaman ini diikuti dengan bagian kedelapan yang merupakan model yang menampilkan simulasi langkah-langkah dalam melakukan jenis praktikum tertentu dalam bentuk visual. Simulasi tersebut antara lain adalah cara mengidentifikasi dan mengklasifikasi larutan berdasarkan sifat asam basa menggunakan indikator baik berupa kertas maupun larutan menggunakan pelat tetes, cara menentukan $\mathrm{pH}$ suatu larutan menggunakan indikator baik kertas strip maupun larutan yang memiliki range $\mathrm{pH}$ tertentu, serta cara menentukan konsentrasi suatu larutan menggunakan metode titrasi. Tampilan Halaman petunjuk verbal dan Halaman simulasi visual disajikan pada gambar 8 dan 9 . 


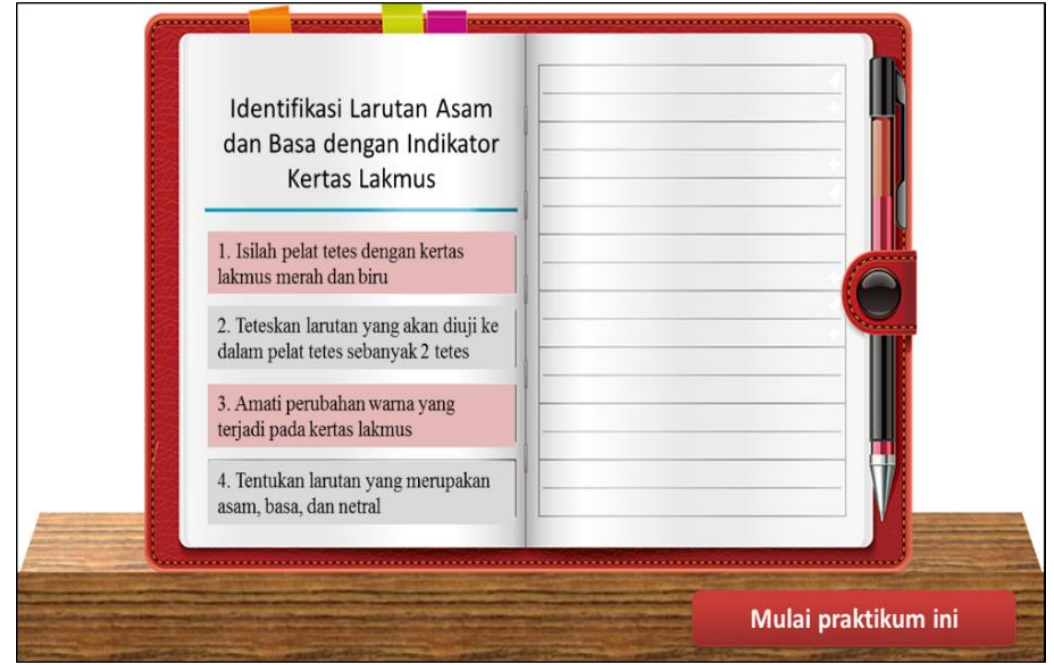

Gambar 8. Contoh Halaman Petunjuk Langkah-Langkah Simulasi Praktikum pada Aplikasi ABC Lab

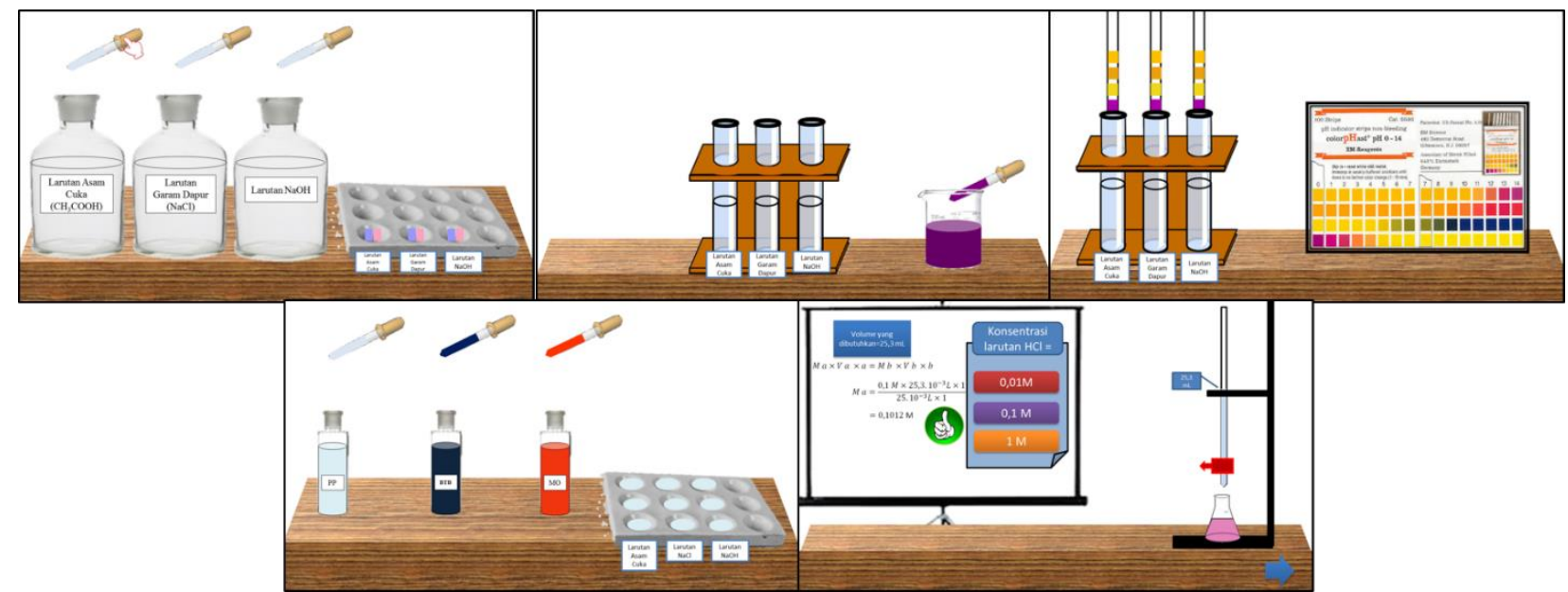

Gambar 9. Contoh Halaman Simulasi Praktikum pada Aplikasi ABC Lab

Bagian kelima hingga kedelapan bertujuan untuk melatih keterampilan psikomotorik siswa. Keterampilan psikomotoik berkaitan dengan performansi aktivitas teknik laboratorium. Melalui latihan simulasi melakukan praktikum menggunakan virtual lab, siswa diharapkan menjadi lebih siap ketika melakukan praktikum di laboratorium real. Martinez-Jimenez et al. (2003) menyatakan bahwa banyak hasil penelitian menunjukkan keunggulan virtual lab sebagai alat bantu siswa dalam pembelajaran mandiri untuk mempersiapkan kegiatan dalam laboratorium real. Keunggulan tersebut bahkan terbukti dapat meningkatkan keterampilan teknik laboratorium siswa ketika melakukan aktivitas pembelajaran di laboratorium real. Woodfield et al. (2005) melaporkan hasil penelitian tentang peningkatan aktivitas pembelajaran siswa ketika melakukan praktikum di laboratorium real pada matapelajaran kimia sebagai dampak penggunaan virtual lab. Ketika pembelajaran laboratorium real difasilitasi dengan virtual lab, siswa menjadi lebih memahami detail prosedur atau teknik laboratorium yang sedang dikerjakan. Hal ini selain membuat waktu praktikum menjadi lebih efisien, siswa juga menjadi lebih difokuskan pada pengembangan kemampuan berpikir tingkat tinggi.

Bagian kesembilan adalah Halaman Analisis data hasil praktikum. Halaman ini menampilkan cara bagaimana menginterpretasi suatu data hasil praktikum antara lain menentukan jenis larutan berdasarkan perubahan warna indikator, menentukan $\mathrm{pH}$ larutan berdasarkan perubahan warna indikator kertas strip atau larutan indikator yang memiliki range $\mathrm{pH}$ tertentu, menentukan konsentrasi suatu larutan berdasarkan data hasil titrasi, serta menentukan titik ekivalen suatu titrasi. Halaman ini juga dilengkapi dengan penjelasan secara konseptual yang menghubungkan aspek 
makroskopik, sub-mikroskopik, dan simbolik. Sebagai contoh penjelasan perubahan $\mathrm{pH}$ selama proses titrasi asam kuat-basa lemah (makroskopik) ditunjukkan melalui gambaran partikel spesies yang ada pada masing-masing titik $\mathrm{pH}$ tertentu (sub-mikorskopik) kemudian dihubungkan dengan kurva titrasi (simbolik). Tampilan halaman analisis data hasil praktikum disajikan pada Gambar 10.

Keunggulan virtual lab yang mampu menampilkan model visual untuk menjangkau konsep dengan representasi hingga pada level sub-mikroskopik sebagaimana ditunjukkan pada bagian kesembilan diharapkan dapat menunjang dan meningkatkan pemahaman konseptual siswa melalui kegiatan praktikum, terutama materi asam basa. Keunggulan ini yang umumnya tidak dimiliki laboratorium konvensional. Dalgarno (et al., 2009) menyatakan bahwa virtual lab telah digunakan dalam dua tujuan pembelajaran kimia. Pertama, virtual lab digunakan untuk menunjukkan dan memberikan konsep kimia kepada siswa berupa representasi visual. Kedua, virtual lab digunakan untuk menyiapkan siswa dalam melakukan kegiatan laboratorium. Pernyataan tersebut dikuatkan oleh pendapat Herga (et al., 2016) bahwa penggunaan virtual lab yang menyajikan visualisasi hingga pada tingkat sub-mikroskopis mampu berperan sebagai cara untuk menarik minat siswa dalam mempelajari suatu konsep yang dianggap membosankan.

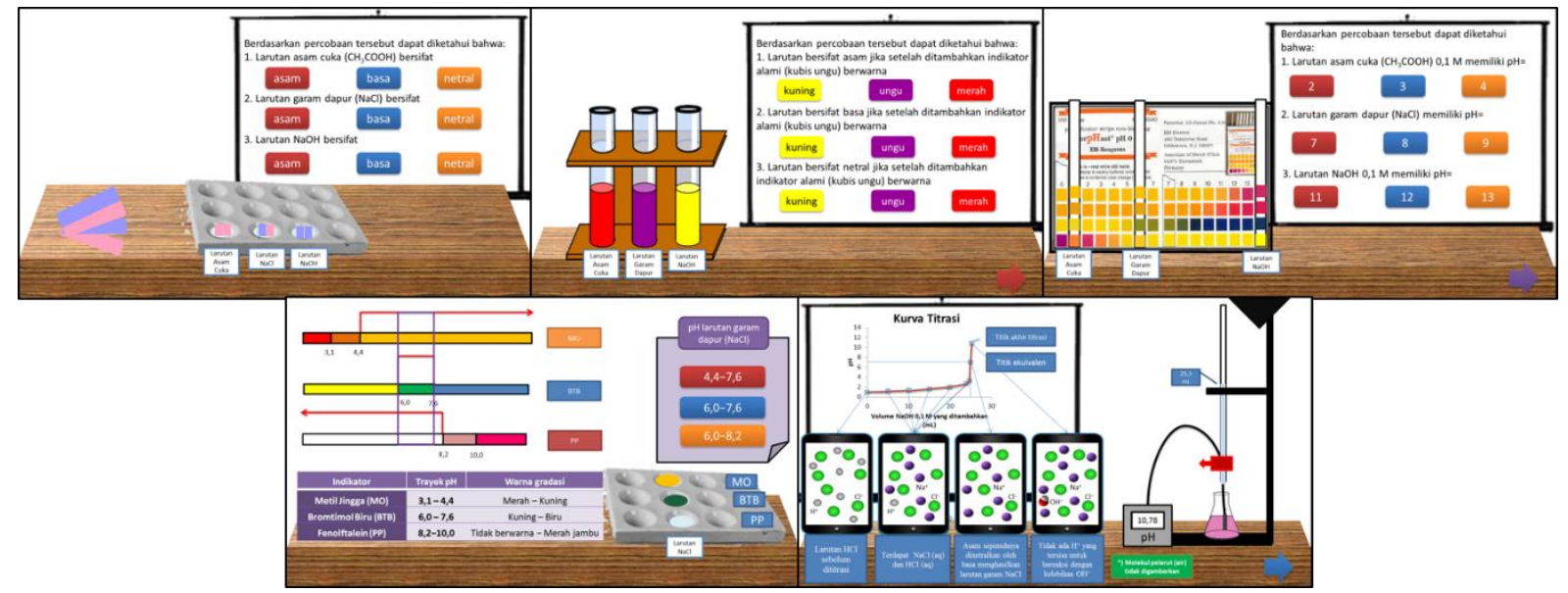

Gambar 10. Contoh Halaman Kesimpulan Simulasi Praktikum pada Aplikasi ABC Lab

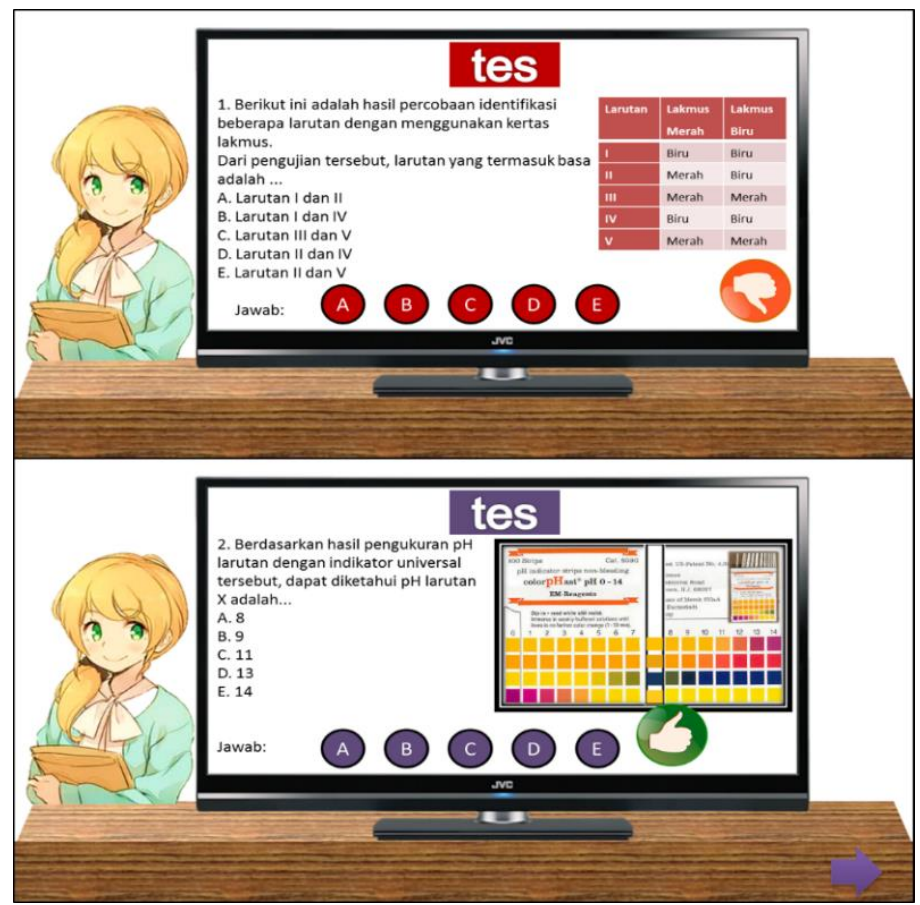

Gambar 11. Contoh Halaman Soal Posttest pada Aplikasi ABC Lab 
Bagian kesepuluh adalah Halaman soal posttest untuk mengukur pemahaman yang telah dicapai siswa setelah melakukan simulasi praktikum. Tampilan halaman soal posttest disajikan pada Gambar 11. Bagian terakhir merupakan Halaman informasi tentang aplikasi ABC Lab yang berisi informasi mengenai aplikasi virtual lab, dan identitas pengembang. Tampilan halaman informasi tentang aplikasi ABC Lab disajikan pada Gambar 12.

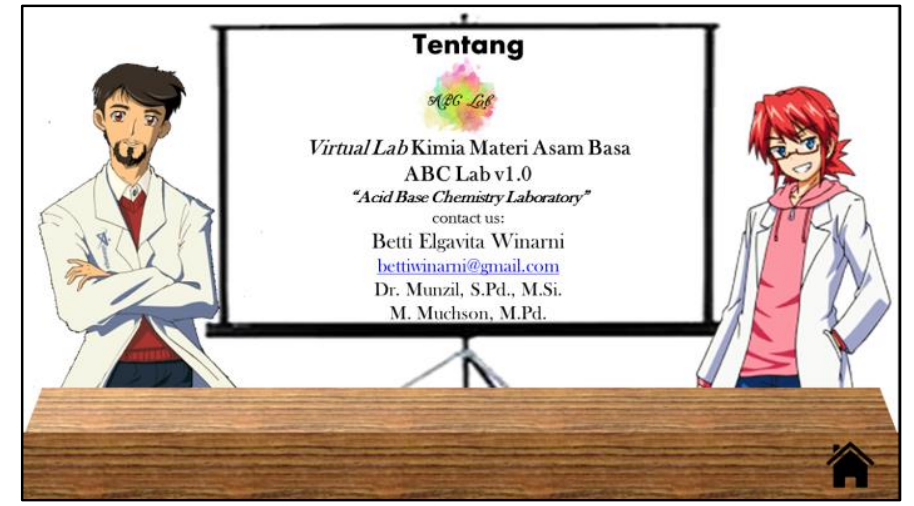

\section{Gambar 12. Contoh Halaman Informasi tentang aplikasi ABC Lab}

Persentase tingkat kelayakan virtual lab hasil pengembangan dari segi fungsinya sebagai media pembelajaran berdasarkan hasil penilaian pakar dan penggunaadalah sebesar 85,44\%; sehingga dapat dikategorikan sangat layak untuk diimplementasikan. Ringkasan data hasil penilaian virtual lab dari segi fungsinya sebagai media pembelajaran disajikan pada Tabel 1.

Tabel 1. Data Hasil Penilaian Kelayakan Virtual lab Hasil Pengembangan sebagai Media Pembelajaran Berdasarkan Perhitungan Nilai Persentase Rata-rata

\begin{tabular}{clcc}
\hline No. & \multicolumn{1}{c}{ Kriteria yang Dinilai } & Persentase (\%) & Kriteria \\
\hline 1. & Tampilan Awal (Cover) & 83,33 & Sangat Layak \\
2. & Tampilan Menu Pre-tes dan Soal Pre-Tes & 84,44 & Sangat Layak \\
3. & Tampilan Menu Utama (Menu Pilihan Praktikum) & 82,22 & Sangat Layak \\
4. & Halaman Simulasi Praktikum Identifikasi Larutan Asam & 93,33 & Sangat Layak \\
& dan Basa & 86,46 & Sangat Layak \\
5. & Halaman Simulasi Praktikum Pengukuran pH Larutan & 88,33 & Sangat Layak \\
& $\quad$ Halaman Simulasi Praktikum Titrasi Asam-Basa & 80,00 & Sangat Layak \\
6. & Virtual lab yang dikembangkan dapat digunakan sebagai \\
7. & & $\mathbf{8 5 , 4 4}$ & Persentase Rata-rata
\end{tabular}

Persentase tingkat kelayakan virtual lab hasil pengembangan dari segi kebenaran dan kejelasan konsep materi berdasarkan hasil penilaian pakar dan pengguna adalah sebesar 84,67\%; sehingga dikategorikan sangat layak untuk diimplementasikan. Ringkasan data hasil penilaian virtual lab dari segi kebenaran konsep materi disajikan pada Tabel 2.

Tabel 2. Data Hasil Penilaian Kelayakan Produk Pengembangan dari Segi Kebenaran dan Kejelasan Konsep Materi Berdasarkan Perhitungan Nilai Persentase Rata-rata

\begin{tabular}{llcc}
\hline No. & \multicolumn{1}{c}{ Kriteria yang Dinilai } & Persentase (\%) & Kriteria \\
\hline 1. & Pre-Tes & 83,33 & Sangat Layak \\
2. & Praktikum Identifikasi Larutan Asam dan Basa & 86,67 & Sangat Layak \\
& & & Sangat Layak \\
3. & Praktikum Pengukuran pH Larutan & 86,67 & Sangat Layak \\
4. & Praktikum Titrasi Asam-Basa & 86,67 & Layak \\
5. & Virtual lab yang dikembangkan dapat digunakan sebagai alat & 80,00 & Sangat Layak \\
\hline & bantu dalam pembelajaran praktikum asam dan basa & & $\mathbf{8 4 , 6 7}$ \\
\hline
\end{tabular}


Komentar dan saran pakar dan pengguna terhadap virtual lab hasil pengembangan dari segi fungsinya sebagai media pembelajaran dijadikan acuan dalam melakukan revisi untuk menghasilkan produk yang lebih baik. Komentar dan saran tersebut serta revisi yang dilakukan terhadap virtual lab hasil pengembangan disajikan pada Tabel 3.

Tabel 3. Revisi yang Dilakukan Berdasarkan Saran dan Komentar Pakar dan Pengguna

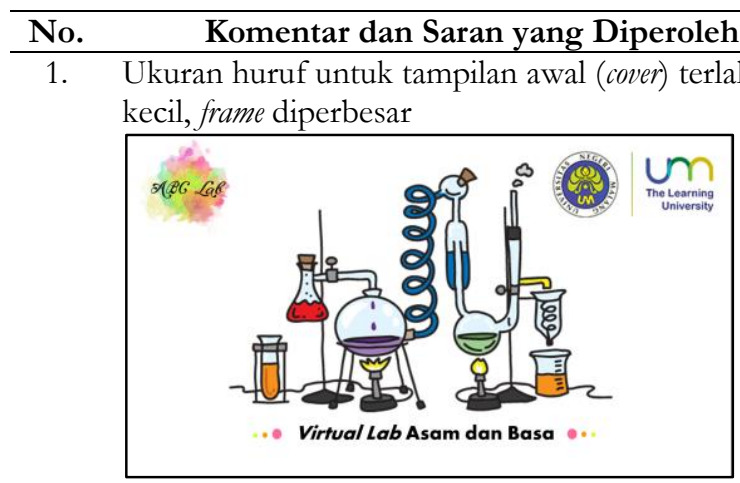

2. Ukuran huruf pada menu pilihan praktikum terlalu kecil dan gambar buku petunjuk praktikum kurang seimbang

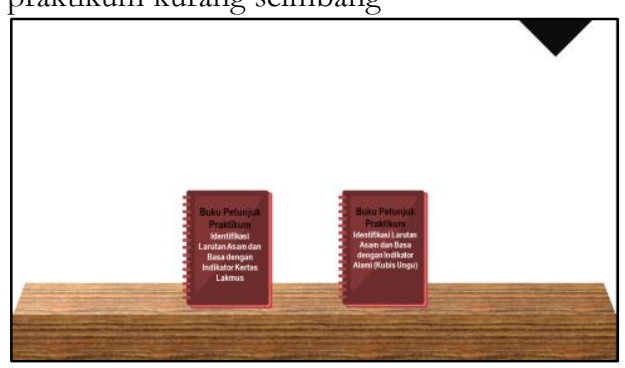

3. Warna kertas lakmus disesuaikan dengan fakta yang ada

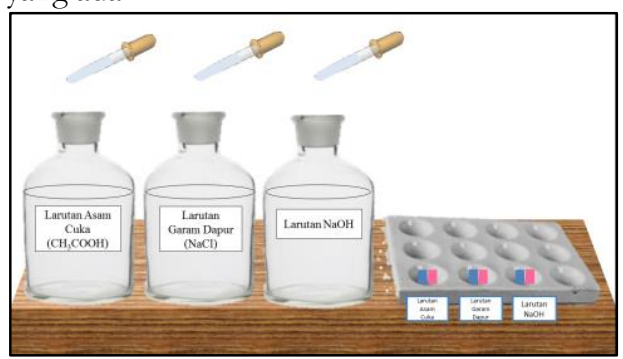

4. Sebaiknya diberikan lembar pengamatan dan perhitungan/buram

5. Animasi yang ada diperhalus gerakannya dan dipercepat animasinya
Revisi yang Dilakukan

Memperbesar ukuran huruf untuk tampilan awal (cover) dan frame

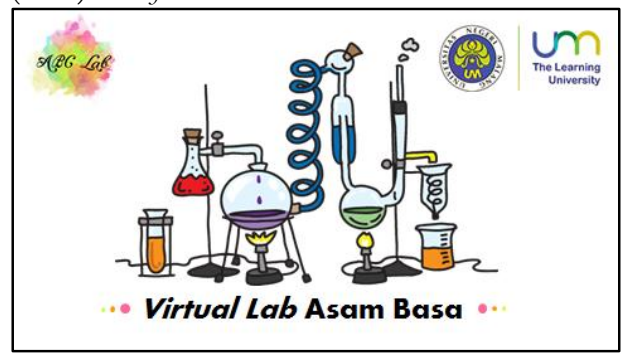

Memperbesar ukuran huruf dan gambar buku agar seimbang dengan ukuran halaman

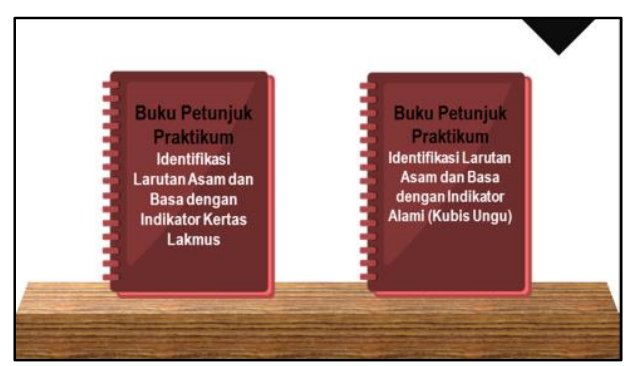

Mengganti warna kertas lakmus berdasarkan fakta yang ada

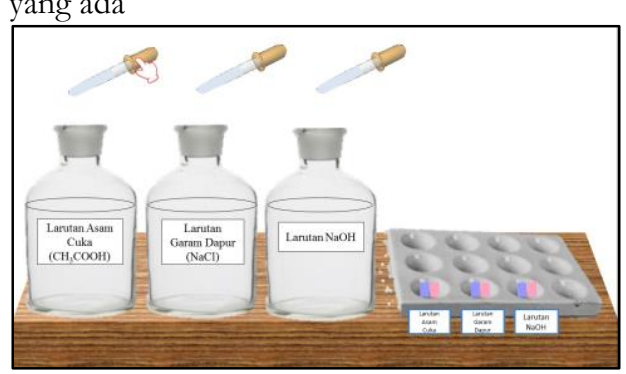

Memberikan lembar pengamatan pada setiap simulasi dan lembar perhitungan/buram pada simulasi yang memerlukan perhitungan

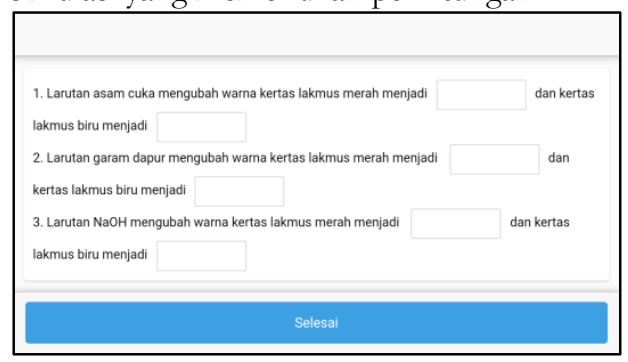

Memperhalus gerakan animasi dan mempercepat waktu gerak animasi

Komentar dan saran pakar, pengguna dan siswa terhadap virtual lab hasil pengembangan dari segi kebenaran dan kejelasan konsep materi juga dijadikan acuan dalam melakukan revisi. Komentar dan saran tersebut serta revisi yang dilakukan terhadap virtual lab hasil pengembangan disajikan pada Tabel 4 dan Tabel 5. 
Uji coba kelompok kecil dilakukan dengan menggunakan virtual lab hasil pengembangan yang telah direvisi berdasarkan komentar dan saran dari validator. Subjek uji coba adalah 12 siswa yang terdiri dari kelas XI IPA 2, XI IPA 5, dan XI IPA 6 SMAN 8 Malang. Persentase persepsi kuantitatif subjek uji coba terhadap penggunaan virtual lab hasil pengembangan adalah sebesar 89,27\%. Data persepsi kuantitatif hasil uji coba kelompok kecil disajikan pada Tabel 6.

Tabel 4. Revisi yang Dilakukan Berdasarkan Saran yang Diperoleh dari Pakar dan Pengguna

\begin{tabular}{|c|c|c|}
\hline No. & Saran yang Diperoleh & Revisi yang Dilakukan \\
\hline \multirow[t]{3}{*}{1.} & Opsi pilihan pada soal pre-tes masih ambigu & Mengganti opsi pilihan pada soal pre-tes agar lebih \\
\hline & tes & setara dan tidak ambigu \\
\hline & 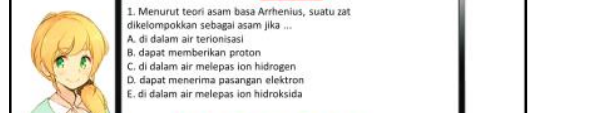 & 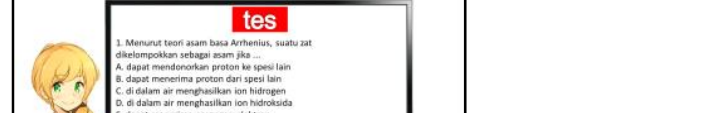 \\
\hline 2. & $\begin{array}{l}\text { Memberikan soal yang variatif dan lebih sulit } \\
\text { (menuju HOTS) }\end{array}$ & $\begin{array}{l}\text { Mengganti soal yang ada pada pos-tes menjadi lebih } \\
\text { variatif dengan tingkat kesulitan mencapai HOTS }\end{array}$ \\
\hline
\end{tabular}

Tabel 5. Revisi yang Dilakukan Berdasarkan Saran yang Diperoleh dari Siswa

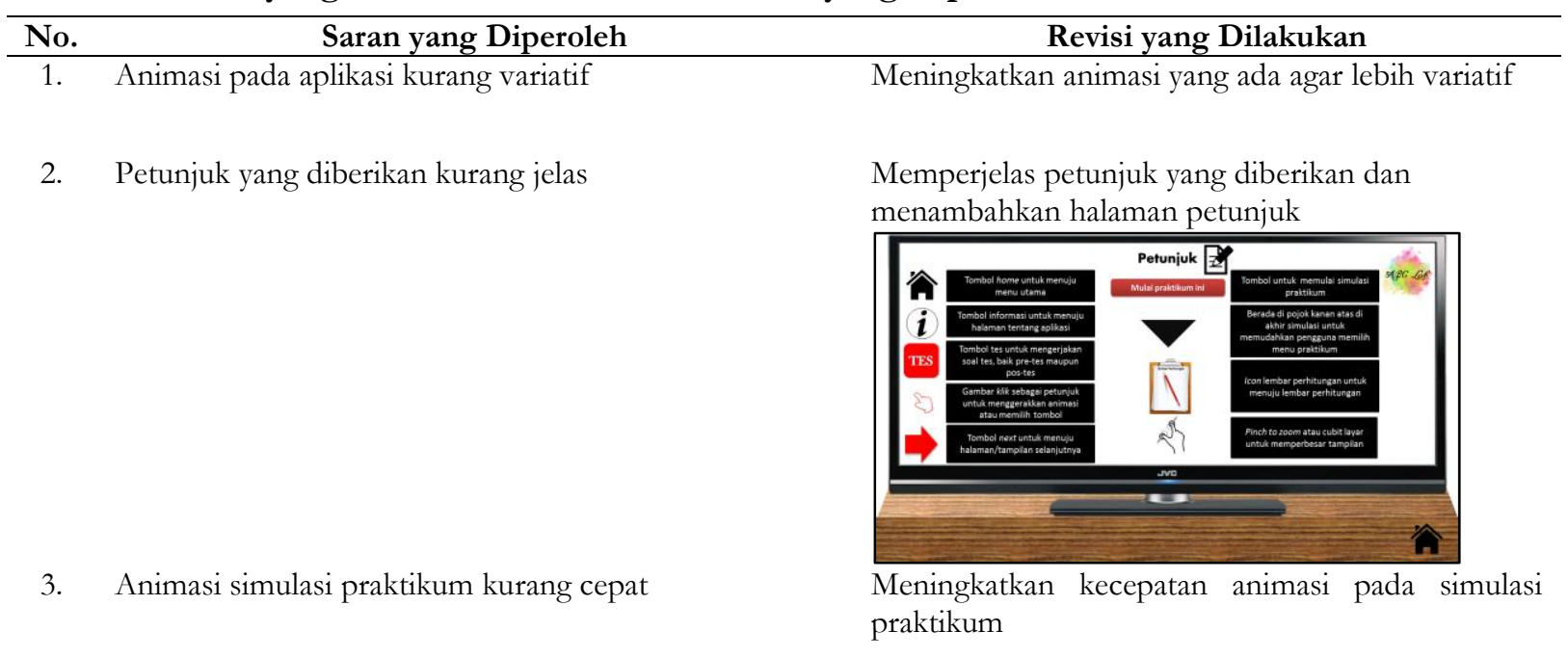

Tabel 6. Data Persepsi Kuantitatif Hasil Uji Coba Kelompok Kecil

\begin{tabular}{clcc}
\hline No. & \multicolumn{1}{c}{ Kriteria yang Dinilai } & Persentase (\%) & Kriteria \\
\hline 1. & Penyajian Media & 90,83 & Sangat Layak \\
2. & Kejelasan Informasi & 92,08 & Sangat Layak \\
3. & Pemakaian Program & 86,67 & Sangat Layak \\
4. & Keefektifan Media & 87,50 & Sangat Layak \\
\hline & Persentase Rata-rata & $\mathbf{8 9 , 2 7}$ & Sangat Layak \\
\hline
\end{tabular}

\section{KESIMPULAN}

Persentase kelayakan virtual lab pada materi asam basa untuk siswa SMA yang telah dikembangkan berdasarkan hasil penilaian pakar dan pengguna dari segi fungsinya sebagai media pembelajaran adalah sebesar 85,44\%; sedangkan dari segi kebenaran dan kejelasan konsep materi adalah sebesar 84,67\%; sehingga virtual lab hasil pengembangan dapat dikategorikan sangat layak untuk diimplementasikan dalam pembelajaran. Persentase tingkat persepsi kuantitatif siswa terhadap penggunaan virtual lab hasil pengembangan berdasarkan hasil uji coba sebesar $89,27 \%$ mendukung tingkat kelayakan produk untuk menjadi sebuah media penunjang dalam pembelajaran materi titrasi asam basa menggunakan metode praktikum. 
Keunggulan produk virtual lab hasil pengembangan antara lain: (1) produk dilengkapi dengan pretes untuk menunjang kesiapan siswa terkait materi yang akan dipraktikumkan dan postes untuk mengukur tingkat pencapaian pemahaman siswa setelah menggunakan produk; serta (2) produk dilengkapi dengan visualisasi partikulat yang menunjang pemahaman siswa terhadap konsepkonsep yang mengandung representasi hingga level sub-mikroskopik; (3) produk dapat digunakan secara linier atau nonlinier dengan memilih menu praktikum yang ingin disimulasikan; (4) efisiensi alat, bahan dan waktu meskipun simulasi praktikum dilakukan sesering yang diinginkan siswa. Kelemahan virtual lab hasil pengembangan antara lain: (1) produk hanya dapat dijalankan secara maksimal pada smartphone berbasis android dengan versi 5.0 (Lollipop)-7.0 (Nougat); (2) ketajaman warna yang ditampilkan pada produk tergantung resolusi/kerapatan pixel smartphone yang digunakan; serta

Saran untuk kajian lebih lanjut terhadap virtual lab hasil pengembanganadalah dilakukan penelitian berbasis metode gabungan kuantitatif-kualitatif untuk menentukan tingkat efektivitas dan mendeskripsikan temuan-temuan terkait implementasi virtual lab hasil pengembangan dalam pembelajaran di kelas. Potensi virtual lab hasil pengembangan untuk menjadi bahan ajar dalam dalam pembelajaran berbasis e-learning juga perlu dikaji lebih lanjut dalam suatu penelitian.

\section{DAFTAR RUJUKAN}

Amry, U. W. (2013). Pengembangan Multimedia Pembelajaran Praktikum Titrasi Asam Basa. Skripsi tidak diterbitkan. Malang: FMIPA UM.

Arsyad, A. (2014). Media Pembelajaran. Jakarta: Rajawali Pers.

Buck, L.B., Lowery Bretz, S., and Towns, M.H. 2008. Characterizing the level of inquiry in the undergraduate laboratory. Journal of College Science Teaching, 38, 52-58.

Chao, L. 2012. Deployment of mobile learning course materials to android powered mobile devices. International Journal of Distance Education Technologies, 10(3), 1-16. DOI: 10.4018/jdet.2012070101.

Dalgarno, B., et al. 2009. Effectiveness of a virtual laboratory as a preparatory resource for distance education chemistry students. Computers \& Education, 53(3), 853-865. DOI:10.1016/j.compedu.2009.05.005.

Hawkins, I. \& Phelps, A. J. 2013. Virtual laboratory vs. traditional laboratory: which is more effective for teaching electrochemistry? Chemistry Education Research and Practice, 14, 516-523. DOI: $10.1039 / \mathrm{c} 3 \mathrm{rp} 00070 \mathrm{~b}$.

Herga, N. R., et al. 2016. Virtual laboratory in the roleof dynamic visualisation for better understanding of chemistry inprimary school. International Journal of Mathematics, Science \& Technology Education, 3(12), 593-608.

Huang, C. 2004. Virtual labs: E-learning for tomorrow. PLoS Biology, 2(6), 734-735. DOI: 10.1371/journal.pbio.0020157.

Jagodzinsky, P. \& Wolski, R. 2015. Assesment of application technology of natural user interfaces in the creation of a virtual chemical laboratory. Journal Science Education and Technology, 24(1), 16-28. DOI: 10.1007/s10956-014-9517-5.

Jiménez, P.M., Pedrajas, A.P., Polo, J., \& Bellido, M.S.C. 2003. Learning in chemistry with virtual laboratories. Journal of Chemical Education, 80(3), 346-352. DOI: 10.1021/ed080p346. 
Jong, Ton de., et al. 2013. Physical and virtual laboratories in science and engineering education. American Assocation for the Advancement of Science, 340(6130), 305-308. DOI: 10.1126/science. 1230579

Kurbanoglu, N.I. \& Akim, A. 2010. The relationships between university students' chemistry laboratory anxiety, attitudes, and self-efficacy beliefs. Australian Journal of Teacher Education, 35(8), 48-59. Dari http://dx.doi.org/10.14221/ajte.2010v35n8.4.

Lang, J. 2012. Comparative study of hands-on and remote physics labs for first year university level physics students. Transformative Dialogues: Teaching \& Learning Journal, 6(1), 1-25.

Lee, W.W. \& Owens, D.L. 2004. Multimedia-Based Instructional Design, Second Edition. San Fransisco: Pfeiffer.

Lutfi, A. 2017. Pengembangan Media Laboratorium Virtual Bersarana Komputer untuk Melatih Berpikir Kritis pada Pembelajaran Asam, Basa, dan Garam. JPPMS, 1(1), 26-33. Dari http://journal.unesa.ac.id/index.php/jppms.

Makransky, G., Thisgaard, M. W. \& Gadegaard, H. 2016. Virtual simulations as preparation for lab exercises: Assessing learning of key laboratory skills in microbiology and improvement of essential non-cognitive skills. PLoS ONE, 11(6), 1-11. DOI: 10.1371/journal.pone.0155895.

Martinez-Jimenez, P., Pontes-Pedrajas, A., Polo, J., \& Climent-Bellido, M. S. (2003). Learning in chemistry with virtual laboratories. Journal of Chemical Education, 80(3), 346-352.

Rahayu, S., Chandrasegaran, A.L., Treagust, D.F., Kita, M., \& Ibnu, S. 2011. Understanding acidbase concepts: Evaluating the efficacy of a senior high school student-centred instructional program in Indonesia. International Journal of Science and Mathematics Education, 9(6), 1439-1458. DOI: 10.1007/s10763-010-9272-x.

Scheckler, R. K. 2003. Virtual labs: A substitute for traditional labs?. International Journal of Developmental Biology, 47: 231-236. http://www.ijdb.ehu.es/web/descarga/paper/12705675.

Sheppard, K. 2006. High school students' understanding of titrations and related acid-base phenomena. Chemistry Education Research and Practice, 7(1), 32-45. DOI: 10.1039/B5RP90014J.

Tarwiyah, I. 2014. Pengembangan Simulasi Virtual Laboratory Larutan Asam-Basa untuk Membangun Konsep dan Keterampilan Proses Sains. Tesis tidak diterbitkan. Bandung: FMIPA UPI.

Tatli, Z. \& Ayas, A. 2010. Virtual laboratory applications in chemistry education. Procedia Social and Behavioral Sciences, 9, 938-942. DOI: 10.1016/j.sbspro.2010.12.263.

Woodfield, B. F., Andrus, M. B., Andersen, T., Miller, J., Simmons, B., Stanger, R., et al. (2005). The virtual chem lab project: A realistic and sophisticated simulation of organic synthesis and organic qualitative analysis. Journal of Chemical Education, 82(11), 1728-1735. 